\title{
Farnesyl Diphosphate Synthase: The Art of Compromise between Substrate Selectivity and Stereoselectivity
}

\author{
Hirekodathakallu V. Thulasiram and C. Dale Poulter ${ }^{*}$ \\ 315 South 1400 East RM 2020; Department of Chemistry; University of Utah, Salt Lake City, UT, \\ USA 84112
}

\begin{abstract}
Farnesyl diphosphate (FPP) synthase catalyzes the consecutive head-to-tail condensations of isopentenyl diphosphate (IPP, $\mathrm{C}_{5}$ ) with dimethylallyl diphosphate (DMAPP, $\mathrm{C}_{5}$ ) and geranyl diphosphate (GPP, $\left.\mathrm{C}_{10}\right)$ to give $(E, E)$-FPP $\left(\mathrm{C}_{15}\right)$. The enzyme belongs to a genetically distinct family of chain elongation enzymes that install $E$-double bonds during each addition of a five-carbon isoprene unit. Analysis of the $\mathrm{C}_{10}$ and $\mathrm{C}_{15}$ products from incubations with avian FPP synthase reveals that small amounts of neryl diphosphate $\left(Z-C_{10}\right)$ and $(Z, E)$-FPP are formed along with the $E$-isomers during the $\mathrm{C}_{5} \rightarrow \mathrm{C}_{10}$ and $\mathrm{C}_{10} \rightarrow \mathrm{C}_{15}$ reactions. Similar results were obtained for FPP synthase from Escherichia coli, Artemisia tridentata (sage brush), Pyrococcus furiosus, and Methanobacter thermautotrophicus and for GPP and FPP synthesized in vivo by $E$. coli FPP synthase. When $(R)$ $\left[2-{ }^{2} \mathrm{H}\right] \mathrm{IPP}$ was a substrate for chain elongation, no deuterium was found in the chain elongation products. In contrast, the deuterium in $(S)-\left[2-{ }^{2} \mathrm{H}\right] \mathrm{IPP}$ was incorporated into all of the products. Thus, the pro- $R$ hydrogen at C2 of IPP is lost when the $E$ - and $Z$-double bond isomers are formed. The synthesis of $Z$-double bond isomers by FPP synthase during chain elongation is unexpected for a highly evolved enzyme and probably reflects a compromise between optimizing double bond stereoselectivity and the need to exclude DMAPP from the IPP binding site.
\end{abstract}

Chain elongation is the fundamental building reaction in the isoprenoid pathway. ${ }^{1}$ During this process the growing hydrocarbon chain in an allylic isoprenoid diphosphate is added to isopentenyl diphosphate (IPP). These reactions are catalyzed by polyprenyl diphosphate synthases, a group of prenyltransferases that can be further subdivided into two families according to the stereochemistry, $E$ or $Z$, of the double bond in the newly added isoprene unit. Members of the two families utilize the same chemical mechanism for chain elongation but are genetically unrelated. ${ }^{1}$ Subgroups within each family are selective for the size of the allylic substrate selected for chain elongation and the length of the isoprenoid chain in the final product. Thus, the "trunk" of the isoprenoid biosynthetic pathway is in reality a complex set of trunks that varies from organism to organism rather than a set of linear chain elongation reactions. Members of each family share distinctive highly conserved motifs characteristic of proteins that have evolved from a common ancestor. ${ }^{2,3}$ Members of the $E$-family typically synthesize shorter chain isoprenoid diphosphates found early in the pathway, while members of the $Z$-family synthesize longer chain diphosphates. ${ }^{1}$

Farnesyl diphosphate (FPP) synthase is the prototypal representative of enzymes in the $E$ family. FPP synthase catalyzes two reactions - the sequential addition of the hydrocarbon moieties of dimethylallyl diphosphate $\left(\mathrm{C}_{5}\right)$ and geranyl diphosphate $\left(\mathrm{C}_{10}\right)$ to IPP $\left(\mathrm{C}_{5}\right)$ to give FPP $\left(\mathrm{C}_{15}\right)$. Metabolites derived from FPP are apparently required by all living organisms, and FPP synthase activity appears to be ubiquitous. Because of its central role in isoprenoid 
metabolism, FPP synthase has served as the platform for studying the structure $2,4,5$ and mechanism ${ }^{6,7}$ of $E$-family enzymes. Structural and genetic studies indicate that the all $\alpha$-helical "isoprenoid" fold of FPP synthase ${ }^{2}$ is found in all of the $E$-family chain elongation enzymes ${ }^{4}$ and in more distant relatives that catalyze cyclopropanation reactions in the sterol $^{8}$ and carotenoid ${ }^{9}$ branches of the pathway and terpenoid cyclization reactions. ${ }^{10}$ An ancestral FPP synthase or a closely related relative is probably the protein from which the other enzymes evolved.

The stereochemistry of the two reactions catalyzed by FPP synthase was determined by Cornforth and Popjak as part of their classical work on cholesterol biosynthesis. ${ }^{11}$ They determined the stereochemistry of four distinct events during the chain elongation reaction (see Scheme 1) - (a) the new bond between $\mathrm{C} 1$ of the allylic substrate and C4 of IPP is formed with inversion at $\mathrm{C} 1$ of the allylic substrate, (b) $\mathrm{C} 1$ of the allylic substrate adds to the si-face of the double bond in IPP, (c) a new E-double bond is formed between C2 and C3 in the product, and (d) the pro- $R$ proton is removed from $\mathrm{C} 2$ of IPP. Because of the long evolutionary history of chain elongation and its central role in isoprenoid biosynthesis, it has been assumed that FPP synthase catalyzes the reaction with a high degree of stereoselectivity. We now report that a significant amount of $Z$-double bond isomers are formed during each of the chain elongation steps and present evidence for the conformations of IPP in the active site that lead to the double bond isomers.

\section{EXPERIMENTAL SECTION}

\section{Overproduction and Purification of Recombinant Enzymes}

Stock samples of $E$. coli strains containing the appropriate plasmid (Table 1) were allowed to recover in Luria Bertani (LB) for $90 \mathrm{~min}$ and plated on LB containing the appropriate antibiotic. Overnight cultures grown from single colonies ( $24 \mathrm{~h}$ old) were used to inoculate $1 \mathrm{~L}$ of LB containing appropriate antibiotics. Cultures were grown at $37^{\circ} \mathrm{C}$ and induced with isopropyl $\beta$ - $D$-thiogalactoside (IPTG) to a final concentration of $1 \mathrm{mM}$ when the $\mathrm{OD}_{600}$ reached $0.6-$ 0.8 . After $4 \mathrm{~h}$, the cells were harvested by centrifugation at $7000 \times \mathrm{g}$ and stored at $-80{ }^{\circ} \mathrm{C}$ until needed. Frozen cells were disrupted by sonication in $50 \mathrm{mM}$ phosphate buffer, $\mathrm{pH} 8.0$, containing $300 \mathrm{mM} \mathrm{NaCl}$ and $10 \mathrm{mM}$ imidazole, and the resulting suspension was clarified by centrifugation. Soluble $\mathrm{His}_{6}$-tagged proteins were purified by chromatography on $\mathrm{Ni}^{2+}{ }_{-} \mathrm{NTA}$ agarose (Qiagen, Chatsworth, CA), according to the manufacturer's protocol. Fractions containing pure $\mathrm{His}_{6}$-tagged protein were combined, and solid $\mathrm{NH}_{4} \mathrm{SO}_{4}(47 \mathrm{~g} / 100 \mathrm{~mL})$ was added. Precipitated protein was collected by centrifugation and dissolved in a minimum volume of $20 \mathrm{mM}$ Tris-HCl buffer, $\mathrm{pH} 8.0$, containing 20\% glycerol, and $4 \mathrm{mM}$ DTT. The solubilized protein was dialyzed against the same buffer, flash frozen, and stored at $-80{ }^{\circ} \mathrm{C}$ until needed.

\section{Product Studies}

Enzyme $(200 \mu \mathrm{g})$ was added to $35 \mathrm{mM}$ HEPES buffer, $\mathrm{pH} 7.6$, containing $10 \mathrm{mM} \mathrm{MgCl} 2,5.0$ $\mathrm{mM} \beta$-mercaptoethanol, $200 \mu \mathrm{M}$ allylic substrate, and $200 \mu \mathrm{M}$ IPP to a final volume of 400 $\mu \mathrm{L}$. The mixture was incubated for $2 \mathrm{~h}$ at $30^{\circ} \mathrm{C}\left(60{ }^{\circ} \mathrm{C}\right.$ for the Pyrococcus furiosus and Methanobacterium thermautotrophicus geranylgeranyl diphosphate (GGPP) synthases). After the incubation, $80 \mu \mathrm{L}$ of $500 \mathrm{mM}$ glycine buffer, $\mathrm{pH} 10.5$, containing $5 \mathrm{mM} \mathrm{ZnCl}_{2}$ and 80 units of calf mucosa alkaline phosphatase (Sigma) were added, followed by incubation at $37^{\circ} \mathrm{C}$ for $1 \mathrm{~h}$ to hydrolyze the diphosphate esters. Solid $\mathrm{NaCl}(\sim 0.2 \mathrm{~g})$ was added, and the aqueous phase was extracted three times with $400 \mu \mathrm{L}$ of tert-butyl methyl ether (TBME). The volume of the extract was reduced to $\sim 50 \mu \mathrm{l}$ with a stream of dry nitrogen. A $1 \mu \mathrm{L}$ portion of the extract was analyzed by gas chromatography (GC) on a column $30 \mathrm{~m} \times 0.25 \mathrm{~mm}$ (bore size) $\times 0.25 \mu \mathrm{m}$ (film thickness) DB-5 capillary column ( $\mathrm{J} \& \mathrm{~W}$ Scientific) with a temperature gradient from $60{ }^{\circ} \mathrm{C}$ to $120{ }^{\circ} \mathrm{C}$ at $2{ }^{\circ} \mathrm{C}$ per min followed by a temperature gradient of $120^{\circ} \mathrm{C}$ to $230{ }^{\circ} \mathrm{C}$ at 10 
${ }^{\circ} \mathrm{C}$ per min with a He with a flow rate of $1 \mathrm{~mL} / \mathrm{min}$. Samples were also analyzed by GC-MS using the same conditions.

\section{In vivo studies}

E. coli BL21(DE3)pLysS and E. coli JM101 were transformed with pET15B-His ${ }_{6}$-FDS and pKEN-His ${ }_{6}$-IDI respectively. LB containing ampicillin $(100 \mu \mathrm{g} / \mathrm{mL})$ was inoculated with the transformed cells and incubated on a rotary shaker for $12 \mathrm{~h}$ at $37^{\circ} \mathrm{C}$. The overnight culture was diluted 100 -fold in the same medium and incubated at $37^{\circ} \mathrm{C}$ on a rotary shaker. At $\mathrm{OD}_{600} \sim 0.6$, cells were induced with $1 \mathrm{mM}$ IPTG and were incubated at $30^{\circ} \mathrm{C}$ for $4 \mathrm{~h}$. The cells were collected by centrifugation at $7000 \times \mathrm{g}$, and the pellet was washed three times with double distilled water. The cell pellet was suspended in $35 \mathrm{mM}$ HEPES buffer, $\mathrm{pH} 7.6$ buffer $(\sim 3 \mathrm{~mL} / \mathrm{g}$ of cell paste) and disrupted by sonication. The suspension was centrifuged at 10,000 $\mathrm{g}$ for $30 \mathrm{~min}$, and the supernatant was centrifuged at 100,000 $\mathrm{g}$ for an hour. To a $5 \mathrm{~mL}$ portion of the $100,000 \mathrm{~g}$ supernatant was added $1 \mathrm{~mL}$ of $0.5 \mathrm{M}$ glycine buffer, $\mathrm{pH} 10.5$, containing 200 units of alkaline phosphatase; $0.8 \mathrm{~mL}$ of $100 \mathrm{mM} \mathrm{MgCl}_{2}$ and $1.6 \mathrm{~mL}$ of $50 \mathrm{mM} \mathrm{ZnCl}_{2}$. The mixture was incubated at $37{ }^{\circ} \mathrm{C}$ for $2 \mathrm{~h}$ and then extracted three times with $1 \mathrm{~mL}$ of TBME. The combined organic extracts were concentrated to $\sim 50 \mu \mathrm{L}$ and analyzed by GC and GC-MS.

\section{RESULTS}

\section{Analysis of $\mathrm{C}_{10}$ and $\mathrm{C}_{15}$ products}

The stereochemistry of the $\mathrm{C}_{5} \rightarrow \mathrm{C}_{10}$ and $\mathrm{C}_{10} \rightarrow \mathrm{C}_{15}$ steps of chain elongation was determined for seven $E$-selective enzymes (see Scheme 2). They include two eukaryotic FPP synthases (avian2 and sagebrush ${ }^{13}$ ), a eubacterial FPP synthase (E. coli12), two archaeal bifunctional FPP/GGPP synthases (P. furiosus 15 and M. thermautotrophicus ${ }^{16}$ ), and two proteins with GPP synthase activity (chrysanthemyl diphosphate (CPP) synthase from Artemisia tridentata speciformis 13 and a chimeric enzyme (BglCV) constructed from A. tridentata speciformis FPP synthase and CPP synthase ${ }^{14}$ ). The chain elongation enzymes were incubated with equimolar concentrations of IPP and allylic diphosphate followed by treatment with alkaline phosphatase to hydrolyze the diphosphate esters to their corresponding alcohols. The stereochemistries of the newly formed double bonds in the $\mathrm{C}_{10}$ and $\mathrm{C}_{15}$ alcohols were determined by GC and GC-MS analysis with authentic samples for comparison. A typical set of GC traces is shown in Figure 1, and the results are summarized in Table 2. In each instance the expected $E$-isomer was accompanied by a small, but easily detectable amount of the $Z$ isomer.

For incubations with DMAPP as the starting substrate, the mixture of alcohols, following treatment with phosphatase, included dimethylallyl alcohol from unreacted DMAPP, geraniol $(\mathrm{GOH})$, nerol (NOH), and the $E, E$ - and $Z, E$-isomers of farnesol (FOH). The stereoselectivity for the $\mathrm{C}_{10} \rightarrow \mathrm{C}_{15}$ step was determined from the relative amounts of $E, E-\mathrm{FOH}$ and $Z, E-\mathrm{FOH}$. $E, E-\mathrm{FOH}$ comprised $96-97 \%$ of the mixture of $\mathrm{C}_{15}$ alcohols from bacterial and eukaryotic FPP synthases, and $87-88 \%$ for the archaeal enzymes. The relative amounts of $\mathrm{GOH}$ and $\mathrm{NOH}$ for enzymes that synthesized FPP did not accurately reflect the stereoselectivity of the $\mathrm{C}_{5} \rightarrow$ $\mathrm{C}_{10}$ step because GPP, the normal allylic substrate for the $\mathrm{C}_{10} \rightarrow \mathrm{C}_{15}$ step, is consumed in preference to neryl diphosphate (NPP). In control experiments where IPP was incubated with GPP and NPP, the rate for conversion of NPP to E,Z-FPP was $<5 \%$ of that for conversion of GPP to FPP. Thus, analysis of the peak intensities for $\mathrm{NOH}$ and $\mathrm{GOH}$ overestimates the amount of NPP generated during chain elongation because GPP is consumed preferentially. A peak for $E, Z-F O H$ was not seen in incubations with DMAPP, presumably because of the small amount of NPP formed in the first step of chain elongation and the inefficiency of elongating NPP relative to GPP in the second step. The stereochemistry of the $\mathrm{C}_{5} \rightarrow \mathrm{C}_{10}$ step was determined for $\mathrm{BglCV}$, an engineered version of sagebrush FPP synthase that did not catalyze 
the second step of chain elongation, and CPP synthase, an enzyme with $\mathrm{C}_{5} \rightarrow \mathrm{C}_{10}$ chain elongation activity. The $E / Z$ stereoselectivity measured for $\mathrm{BglCV}$ was similar to those seen for FPP synthases. A substantially higher proportion of NPP, the Z- $\mathrm{C}_{10}$ stereoisomer, was seen for the chain elongation catalyzed by CPP synthase.

\section{Stereochemistry at C2 of IPP}

The stereochemistry for proton elimination at $\mathrm{C} 2$ of IPP during formation of both double bond stereoisomers was determined for the $\mathrm{C}_{5} \rightarrow \mathrm{C}_{10}$ step for $\mathrm{BglCV}$ and the $\mathrm{C}_{5} \rightarrow \mathrm{C}_{10}$ and $\mathrm{C}_{10} \rightarrow$ $\mathrm{C}_{15}$ steps for avian, E. coli, and A. tridentata FPP synthases during incubations with $(R)$ $\left[2-{ }^{2} \mathrm{H}\right] \mathrm{IPP}$ and $(S)-\left[2-{ }^{2} \mathrm{H}\right] \mathrm{IPP}$. The results of GC-MS analysis of the chain elongation alcohols following hydrolysis of the diphosphate esters are shown in Table 3 (mass spectra are shown in Supporting Information). When unlabelled IPP and DMAPP were used as substrate, the EI MS for $\mathrm{GOH}$ and $\mathrm{NOH}$ gave peaks at m/z $154\left(\mathrm{M}^{+}\right), 139\left(\mathrm{M}^{+}-\mathrm{CH}_{3}\right), 136\left(\mathrm{M}^{+}-\mathrm{H}_{2} \mathrm{O}\right), 123$ $\left(\mathrm{M}^{+}-\mathrm{CH}_{2} \mathrm{OH}\right), 121\left(\mathrm{M}^{+}-\mathrm{H}_{2} \mathrm{O}-\mathrm{CH}_{3}\right)$. Similarly, the EI MS of Z,E- and E,E-FOH had peaks at $\mathrm{m} / \mathrm{z} 222\left(\mathrm{M}^{+}\right), 207\left(\mathrm{M}^{+}-\mathrm{CH}_{3}\right), 204\left(\mathrm{M}^{+}-\mathrm{H}_{2} \mathrm{O}\right)$. All of the alcohols gave a m/z 69 base peak for loss of the $\omega$-isoprene unit. For each of the enzymes, deuterium was lost from $\mathrm{C} 2$ of $(R)$ $\left[2-{ }^{2} \mathrm{H}\right] \mathrm{IPP}$ and retained at $\mathrm{C} 2$ of $(S)-\left[2-{ }^{2} \mathrm{H}\right] \mathrm{IPP}$ during the $\mathrm{C}_{5} \rightarrow \mathrm{C}_{10}$ step and the $\mathrm{C}_{10} \rightarrow \mathrm{C}_{15}$ step, regardless of which double bond isomer was produced. When DMAPP was the allylic substrate, incubation with $(R)-\left[2-{ }^{2} \mathrm{H}\right] \mathrm{IPP}$ gave $\mathrm{C}_{10}$ chain elongation alcohols with $\mathrm{m} / \mathrm{z}$ at 154 , 139, 136, 123, and 121 (BglCV) and $\mathrm{C}_{15}$ alcohols with $\mathrm{m} / \mathrm{z}$ at 222, 207, 204 (avian, E. coli, A. tridentata). Similar incubations with $(S)-\left[2-{ }^{2} \mathrm{H}\right] \mathrm{IPP}$ gave peaks at $\mathrm{m} / \mathrm{z} 155,140,137,124$, and 122 for the $\mathrm{C}_{10}$ alcohols and $\mathrm{m} / \mathrm{z} 224,209,206$ (addition of two IPP units) for the $\mathrm{C}_{15}$ alcohols. Related behavior was seen for the $\mathrm{C}_{10} \rightarrow \mathrm{C}_{15}$ step when GPP was the allylic substrate where $(R)-\left[2-{ }^{2} \mathrm{H}\right] \mathrm{IPP}$ gave $\mathrm{C}_{15}$ alcohols whose mass spectra had peaks at $\mathrm{m} / \mathrm{z} 222,207,204$ (avian, E. coli, A. tridentata) and $(S)-\left[2{ }^{2} \mathrm{H}\right] \mathrm{IPP}$ gave alcohols with peaks at $\mathrm{m} / \mathrm{z} 223,208,205$ (addition of one IPP unit).

\section{Double bond stereochemistry in vivo}

E. coli strain BL21 (DE3)pLysS, transformed with a plasmid that directs expression of $E$. coli FPP synthase under control of the T7 promoter, was incubated as described in the Experimental Section. The cell free extract was treated with alkaline phosphatase, the resulting alcohols were extracted with MTBE, and extract was analyzed by GC-MS. The GC profile from single ion monitoring at $\mathrm{m} / \mathrm{z} 69$, the mass of base peak for $E, E$ - and $Z, E-\mathrm{FOH}$, is shown in Figure 2. The peaks at 38.4 and 38.8 min gave mass spectra that were virtually identical to those of $Z, E-\mathrm{FOH}$ and $E, E$-farnesol, respectively. Other peaks gave mass spectra that were not characteristic of mono- or sesquiterpenoid alcohols. Thus, the minor stereoisomer of FPP is synthesized in vivo by $E$. coli from plasmid encoded $E$. coli FPP synthase in a ratio similar to that measured in vitro for the same enzyme.

\section{DISCUSSION}

Isoprenoid chain elongation is generally thought to proceed with a high degree of stereoselectivity characteristic of most enzyme catalyzed reactions. The stereochemistry of the double bonds, particularly the $\mathrm{C} 2-\mathrm{C} 3$ double bond, in the growing hydrocarbon chain of the allylic substrate is important if the intermediate is to serve as a substrate for the next addition of IPP. ${ }^{1} E, E$-FPP, which lies at an important multiple branch point in the isoprenoid pathway, is the precursor for biosynthesis of sterols, ${ }^{17}$ farnesylated proteins, ${ }^{18}$ and sesquiterpenes. ${ }^{10}$ ' FPP is also the allylic primer for the chain elongation enzymes required to synthesize geranylgeranylated proteins, ${ }^{19}$ dolichols, ${ }^{20}$ heme a, ${ }^{21}$ and ubiquinones. ${ }^{22}$ All of these reactions require the $E, E$-stereoisomer. IPP and DMAPP are "expensive" substrates for FPP synthase. IPP is synthesized in six steps, and DMAPP in seven steps, from three molecules acetyl-CoA by the mevalonate pathway. ${ }^{23}$ Both molecules are synthesized in six steps from 
glyceraldehyde phosphate and pyruvate by the methylerythrose phosphate pathway. ${ }^{24}$ One might have expected that FPP synthase, with a history that apparently stretches back to the very beginning of cellular life, would have become highly selective for $E$-chain elongation during the course of its evolution. Our results with eukaryotic, bacterial, and archaeal forms of the enzyme indicate that this is not the case.

A biosynthetic pathway that uses IPP and DMAPP in the first step of chain elongation presents special challenges to FPP synthase. For maximal efficiency, the regions of the active site that bind IPP and DMAPP must distinguish between the two $\mathrm{C}_{5}$ isomers. Although IPP and DMAPP can both bind to the allylic site, ${ }^{25,26}$ this mode of IPP binding does not appear to present a problem. At physiological concentrations of IPP and DMAPP, substrate inhibition due to IPP binding in the allylic site does not appear be important. ${ }^{25}$ In addition, the homoallylic moiety in IPP cannot participate in chain elongation by the well-established step-wise electrophilic alkylation mechanism shown in Scheme 3. ${ }^{6,7}$ In contrast, the double bond in DMAPP is susceptible to electrophilic alkylation. FPP synthase apparently has the ability to exclude that molecule from the IPP binding region to prevent a reaction with itself. ${ }^{14,} 26$ The X-ray structure of the $E$. coli enzyme complexed with IPP and an unreactive thio analogue of DMAPP, 5 provides an explanation for the discrimination against DMAPP at the IPP site based on differences in the conformational flexibility of the two substrates. The orientation of IPP and the thioDMAPP analogue in the E. coli FPP synthase-IPP-thioDMAPP complex (see Figure 3 ) would produce the $E$-stereochemistry during chain elongation by FPP synthase. The hydrocarbon unit of DMAPP is located on the si-face of the C3-C4 double bond in IPP with $\mathrm{C} 1$ positioned for an inversion of configuration upon alkylation. The $\mathrm{C} 1-\mathrm{C} 2 / \mathrm{C} 3-\mathrm{C} 4$ dihedral angle in IPP, $\Theta$ is $118^{\circ}$. In this orientation, a "least motion" elimination of a proton from $\mathrm{C} 2$ would give an $E$-double bond in the allylic product. In addition, the $\mathrm{H}_{\mathrm{R}}$ proton at $\mathrm{C} 2$ in IPP is suitably positioned for elimination, presumably assisted by a non-bridging oxygen atom in the nearby molecule of inorganic pyrophosphate. ${ }^{1}$ DMAPP has a $\mathrm{C} 2-\mathrm{C} 3$ double bond, and as a consequence the $\mathrm{C} 1-\mathrm{C} 2 / \mathrm{C} 3-\mathrm{C} 4$ dihedral angle $\Theta$ s restricted to $180^{\circ}$. The inability of FPP synthase to bind DMAPP at the IPP site can be explained conformational differences between the two substrates; whereas, IPP cannot be readily excluded from the DMAPP site because IPP is a more flexible molecule that can adopt conformations whose topologies are very similar to any of those accessible to DMAPP. This is illustrated in Figure 4 using space-filling representations of IPP and DMAPP. The shape of the conformer of IPP where the five carbon atoms are in the same plane (a and c) is very similar to that of DMAPP (b and d). In contrast, rotation about the $\mathrm{C} 2-\mathrm{C} 3$ bond in IPP, which in not possible for DMAPP, gives a substantially different shape ( $\mathrm{d}$ and $\mathrm{e}$ ).

Why is the degree of stereocontrol exerted by FPP synthase during chain elongation not higher? The observation that the $\mathrm{H}_{\mathrm{R}}$ in IPP is removed when either double bond isomer is formed provides a clue. Presumably the electrophilic alkylation of IPP proceeds with the initial formation of a $\pi$-complex between $\mathrm{C} 1$ of the allylic cation and the double bond, followed by collapse to the $\mathrm{C} 3$ tertiary cation. $27,28,29$ The relative positions of $\mathrm{C} 1$ in the analog and the C3-C4 IPP double bond in the FPP synthase-IPP-thioDMAPP complex are consistent with this scenario. A $180^{\circ}$ rotation about the $\mathrm{C} 2-\mathrm{C} 3$ bond in IPP gives a conformer, $\Theta=62^{\circ}$ that is topologically similar to the $\Theta=118^{\circ}$ conformer (see Figure 4, parts e and f) but which would produce a $Z$-double bond in the chain elongation product. It might be difficult to distinguish between the $\Theta=62^{\circ}$ and $\Theta=118^{\circ}$ conformers of IPP during binding because of their similar topologies. Thus, a relatively small movement of the dimethylallyl cation during alkylation would suffice to alkylate either conformer of IPP with subsequent elimination of $\mathrm{H}_{\mathrm{R}}$, in agreement with our observations.

Bacterial and eukaryotic FPP synthases "waste" approximately $4 \%$ of the available IPP and $2 \%$ of the DMAPP during synthesis of FPP. These numbers increase substantially to $30 \%$ and 
$15 \%$, respectively, for the thermophilic archaeal enzymes. With the possible exception of plants, the $Z-\mathrm{C}_{10}$ and $Z, E-\mathrm{C}_{15}$ double bond isomers do not appear to be utilized in subsequent biosynthetic reactions and are presumably degraded. While this amount of waste is burdensome for synthesis of FPP, it is unsustainable for the longer chain isoprenoid diphosphates required for biosynthesis of ubiquinones or dolicohols. Given the ancient origins of FPP synthase, it seems doubtful that the enzyme can achieve a greater degree of discrimination for different conformers of IPP through continued evolution. In this regard it is interesting to note that the long chain polyprenyl diphosphate synthases use FPP or GGPP instead of DMAPP as the allylic substrate to initiate elongation. Perhaps greater stereocontrol is possible in the long chain enzymes through better immobilization of the carbocationic intermediate as a result of binding interactions between the enzyme and the longer isoprenoid chain.

\section{Supplementary Material}

Refer to Web version on PubMed Central for supplementary material.

\section{ACKOWLEDGEMENTS}

We thank Professor John Vederas for generous samples of $(R)$ - and $(S)-\left[2-{ }^{2} \mathrm{H}\right] \mathrm{IPP}$ and Ms. Mo Chen for providing the plasmid for $E$ coli FDS. This work was supported by National Institutes of Health grant GM 21328.

\section{REFERENCES}

1. Poulter CD. Phytochem. Reviews 2006;5:17-26.

2. Tarshis LC, Yan M, Poulter CD, Sacchettini JC. Biochemistry 1994;33:10871-10877. [PubMed: 8086404]

3. Fujuhashi M, Zhang Y-W, Higuchi Y, Li X-Y, Koyama T, Miki K. Proc Natl. Acad. Sci, USA 2001;98:4337-4342. [PubMed: 11287651]

4. Tarshis LC, Proteau PJ, Kellogg BA, Sacchettini JC, Poulter CD. Proc. Natl. Acad. Sci, USA 1996;93:15018-15023. [PubMed: 8986756]

5. Hosfield DJ, Zhang Y, Dougan DR, Broun A, Tari LW, Swanson RV, Finn J. J. Biol. Chem 2004;279:8526-8529. [PubMed: 14672944]

6. Poulter CD, Rilling HC. Acc. Chem. Res 1978;11:307-313.

7. Poulter CD, Wiggins PL, Le AT. J. Am. Chem. Soc 1981;103:3926-3927.

8. Pandit J, Danley DE, Schulte GK, Mazzalupo S, Pauly TA, Hayward CM, Hamanaka ES, Thompson JF, Harwood HJ. J. Biol Chem 2000;275:30610-30617. [PubMed: 10896663]

9. Blagg BSJ, Jarstfer MB, Rogers DH, Poulter CD. J. Am. Chem. Soc 2002;124:8846-8853. [PubMed: 12137537]

10. Christianson DW. Chem. Rev 2006;106:3412-3442. [PubMed: 16895335]

11. Popjak G, Cornforth JW. Biochem. J 1966;101:553-568. [PubMed: 16742426]

12. Chen M, Poulter CD. unpublished results

13. Hemmerlin A, Rivera SB, Erickson H, Poulter CD. J. Biol. Chem 2003;34:32132-32140. [PubMed: 12782626]

14. Erickson H, Poulter CD. J. Am. Chem. Soc 2003;23:6885-6888.

15. Kidd MT, Poulter CD. unpublished results

16. Chen A, Poulter CD. Arch. Biochem. Biophys 1994;314:399-404. [PubMed: 7979381]

17. Poulter, CD.; Rilling, HC. Conversion of farnesyl pyrophosphate to squalene. In: Porter, JW., editor. Biosynthesis of Isoprenoid Compounds. Volume 1. New York: John Wiley \& Sons; 1981. p. 414-441.

18. Mayer MP, Prestwich GD, Dolence JM, Bond PD, Wu H-y, Poulter CD. Gene 1993;132:41-47. [PubMed: 8406041]

19. Jiang Y, Proteau P, Poulter CD, Ferro-Novick S. J. Biol. Chem 1995;270:21793-21799. [PubMed: 7665600] 
20. Matsuoka S, Sagami H, Kurisaki A, Ogura K. J. Biol Chem 1991;266:3464-3468. [PubMed: 1995611]

21. Weinstein JD, Branchaud R, Beele SI, Bemet WJ, Sinclair PR. Arch. Biochem. Biophys 1986;245:4450. [PubMed: 3947101]

22. Ashby MN, Edwards PA. J. Biol. Chem 1990;265:13157-13164. [PubMed: 2198286]

23. Qureshi, N.; Porter, JW. Conversion of acetyl-coenzyme A to isopentenyl pyrophosphate. In: Porter, JW.; Spurgeon, SL., editors. Biosynthesis of Isoprenoid Compounds. Volume 1. New York: John Wiley and Sons; 1981. p. 47-94.

24. Rohdich F, Kis K, Bacher A, Eisenreich W. Curr. Opinion Chem. Biol 2001;5:535-540.

25. Laskovics FM, Poulter CD. Biochemistry 1981;20:1893-1901. [PubMed: 7013805]

26. King HL, Rilling HC. Biochemistry 1977;16:3815-3819. [PubMed: 901755]

27. Dewar MJS, Reynolds CH. J. Am. Chem. Soc 1984;106:1744-1750.

28. Farcasiu D, Norton SH. J. Org. Chem 1997;62:5374-5379.

29. Farcasiu D, Norton SH, Hancu D. J. Am. Chem. Soc 2000;122:668-676.

\section{Abbreviations}

DMAPP, dimethylallyl diphosphate

$\mathrm{FOH}$, farnesol

FPP, farnesyl diphosphate

$\mathrm{GOH}$, geraniol

GPP, geranyl diphosphate

GGPP, geranylgeranyl diphosphate

IPP, isopentenyl diphosphate

IPTG, isopropyl $\beta$-D-thiogalactoside

LB, Luria Bertani

$\mathrm{NOH}$, nerol

NPP, neryl diphosphate

TBME, tert-butyl methyl ether 


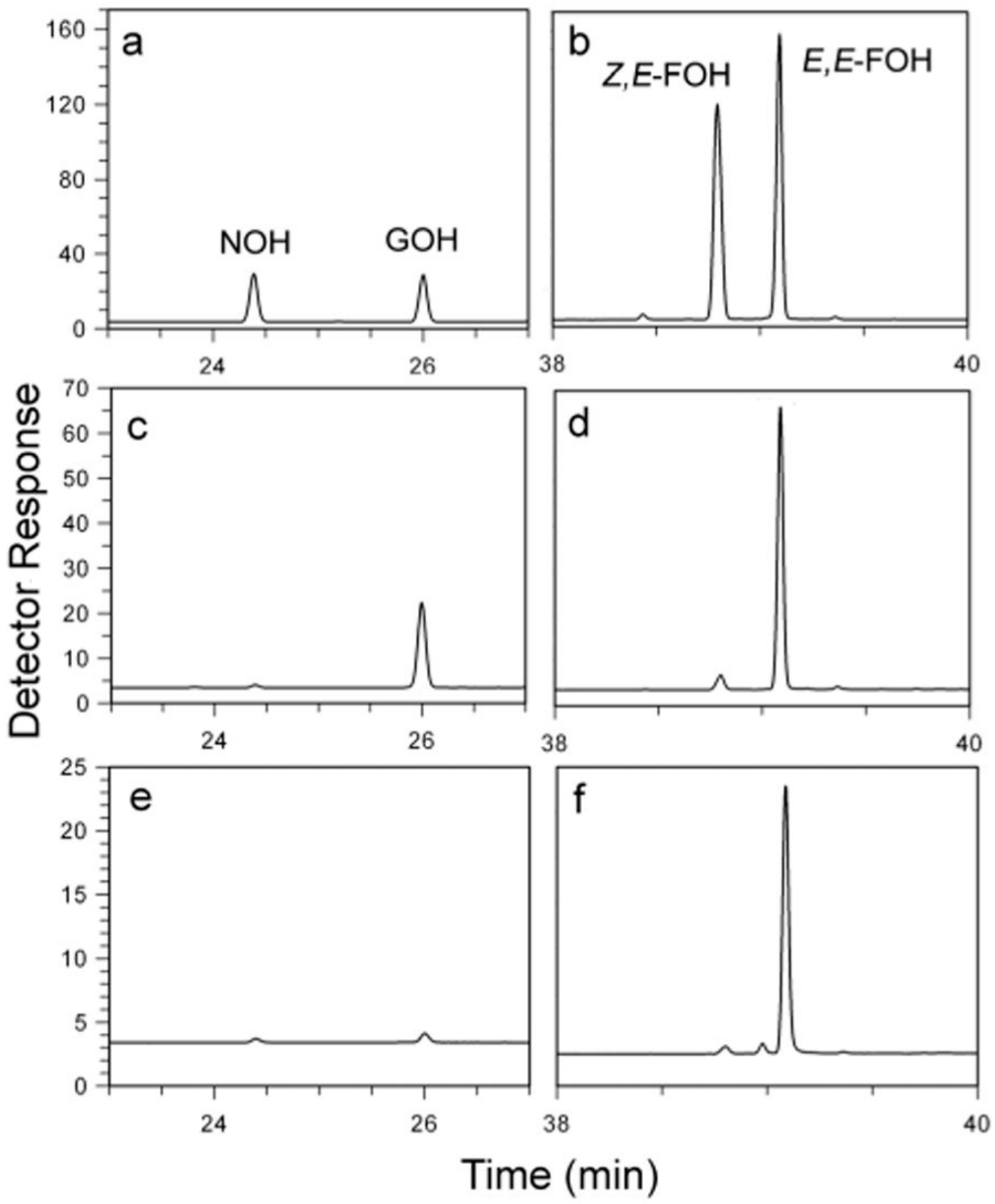

Figure 1.

GC analysis of $\mathrm{C}_{10}$ and $\mathrm{C}_{15}$ alcohols after hydrolysis of chain elongation products from avian FPP synthase. Parts a and b: Authentic samples of NOH $\left(Z-\mathrm{C}_{10}\right), \mathrm{GOH}\left(Z-\mathrm{C}_{10}\right), Z, E-\mathrm{FOH}$ and $Z, E$-FOH. Parts c and d: incubation with IPP and DMAPP. Parts e and f: incubation with IPP and GPP. Minor peaks at 39.0 and 39.4 min are contaminants seen in control incubations without substrate. Conditions are in the Experimental Section. 


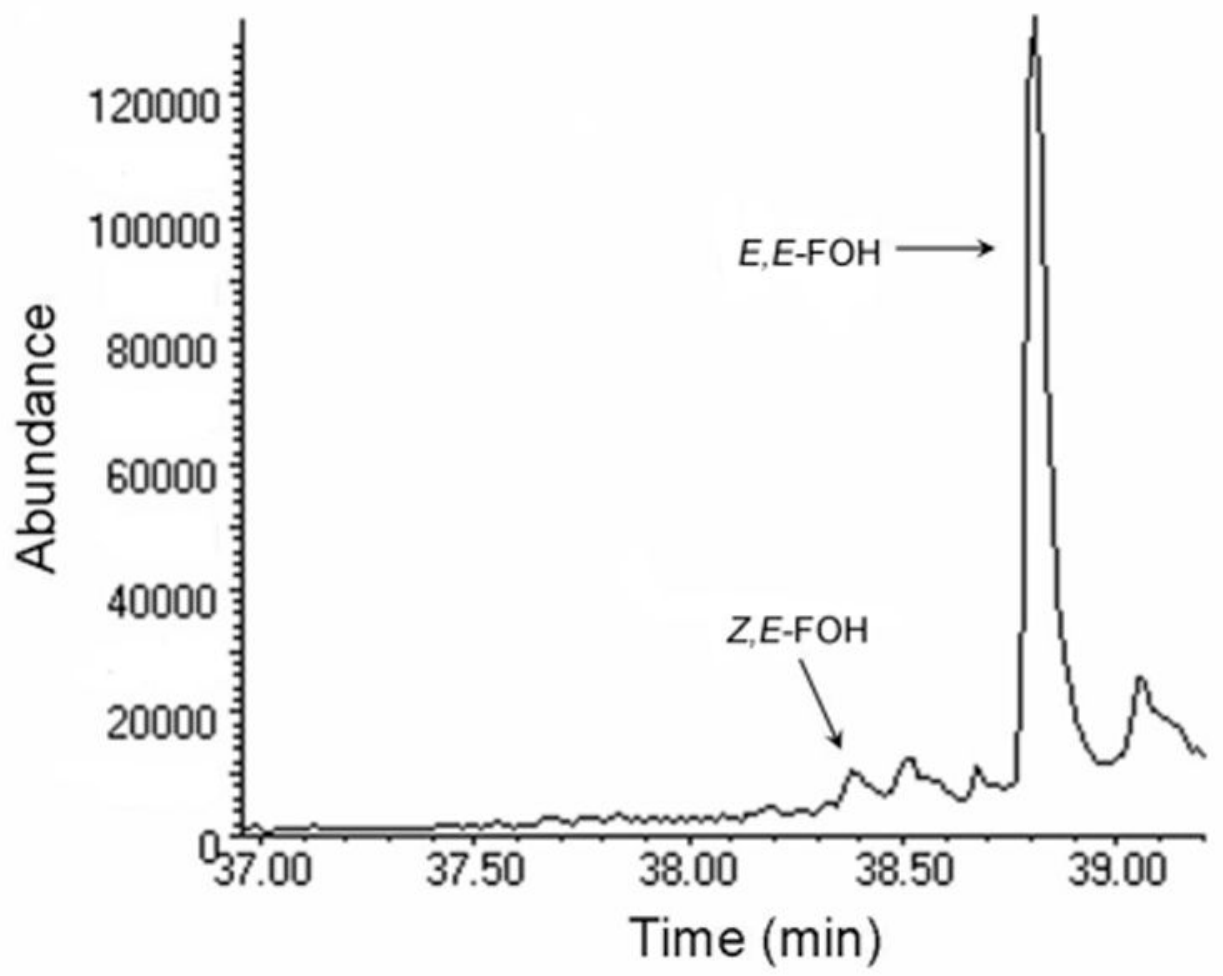

Figure 2.

GC trace of MTBE extracts of cell-free homogenate from E. coli strain BL21(DE3)pLysS/ pET15BEFDS after treatment with alkaline phosphatase. 


\section{IPP}
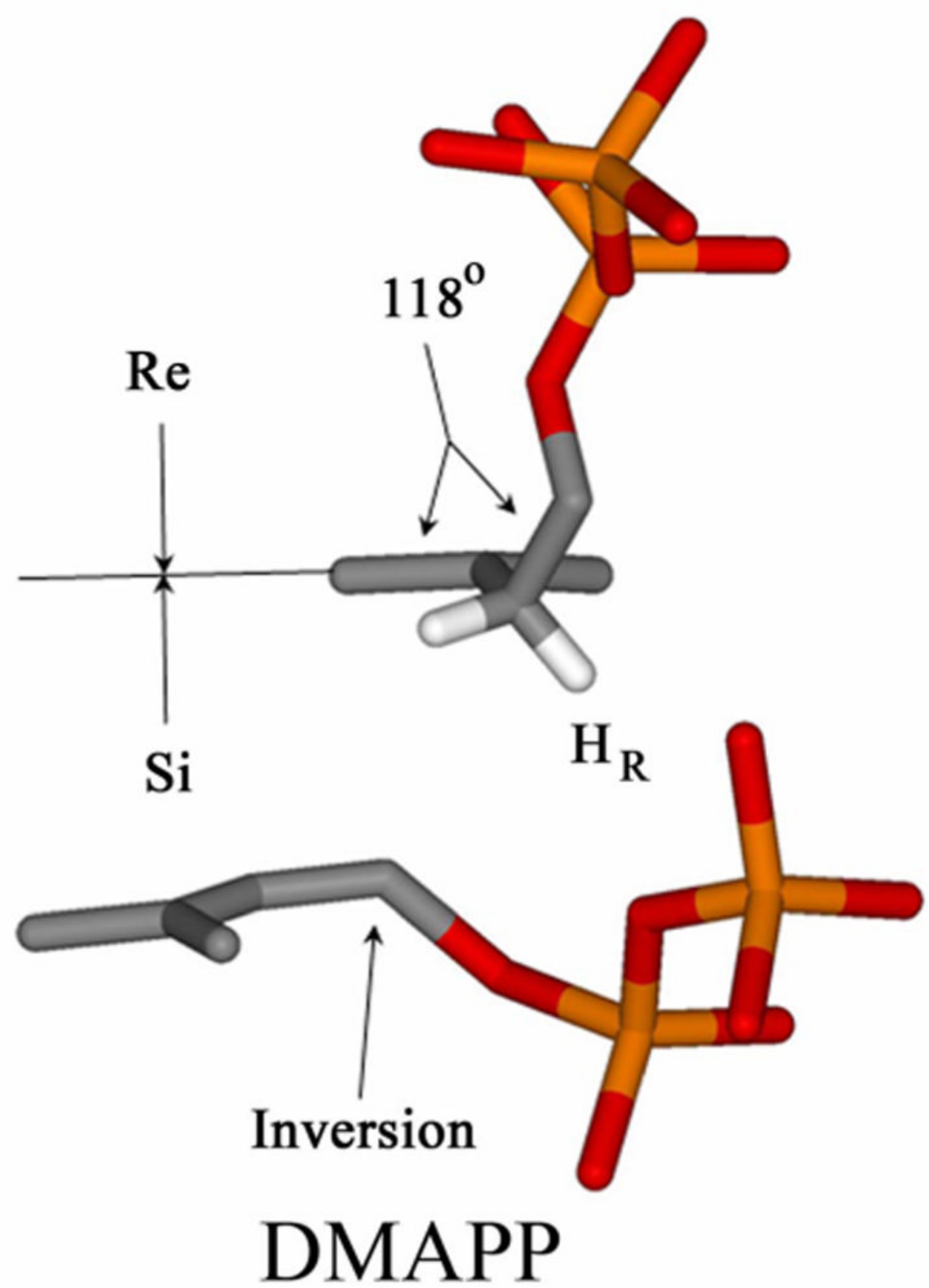

Figure 3.

Orientation of IPP and DMAPP in the active site of $E$. coli FPP synthase highlighting stereochemical features important for E-selective chain elongation. 

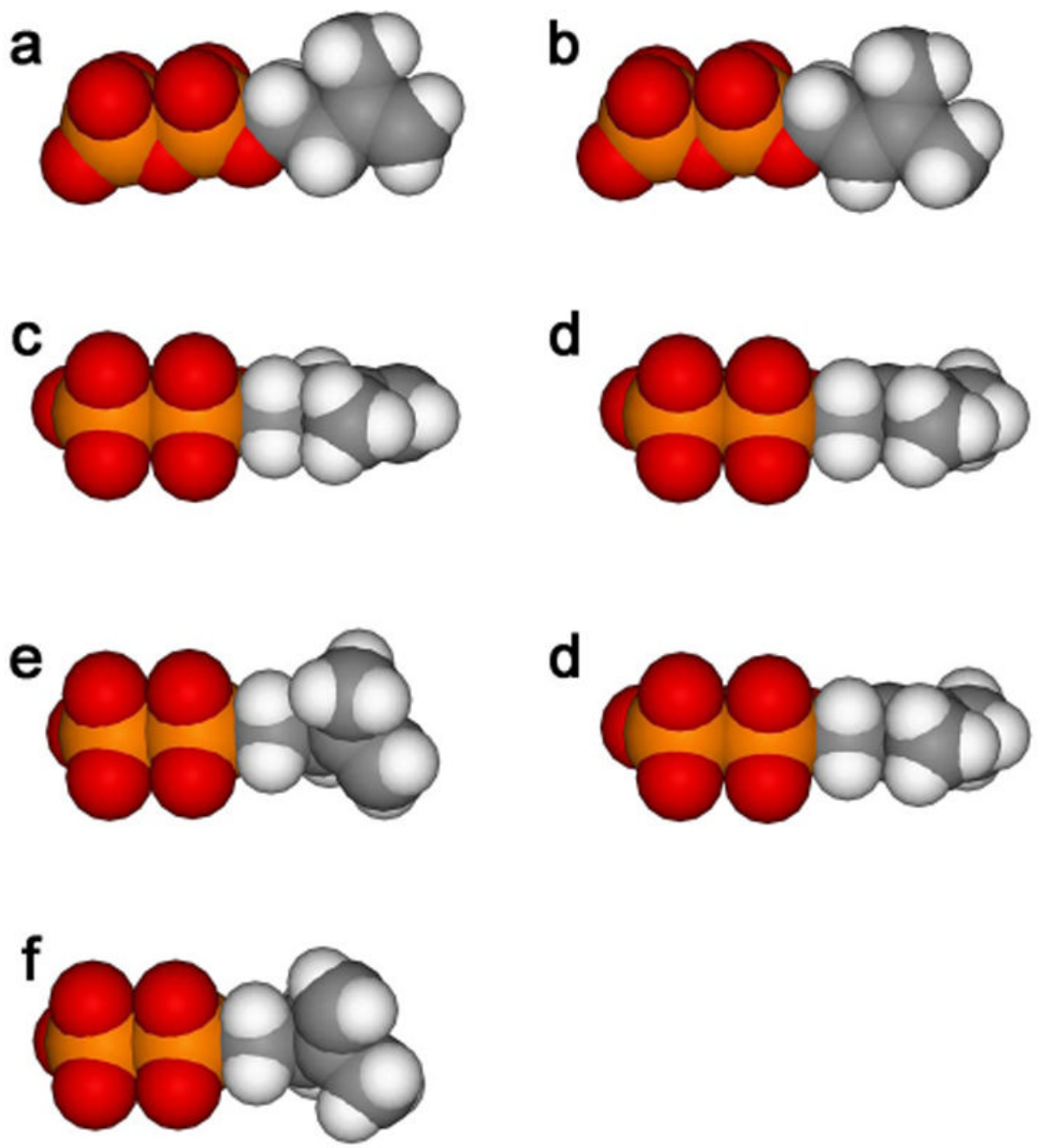

IPP

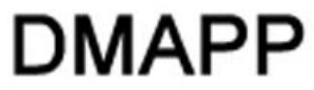

Figure 4.

Space-filling representations of IPP and DMAPP. Parts a and b; both molecules in conformations that allow maximum spatial overlap, viewed from top face of isoprenoid units. Parts $\mathrm{c}$ and d; edge-on view of the conformers shown in parts a and b. Part e; same orientation as part c except the $\mathrm{C} 1-\mathrm{C} 2 / \mathrm{C} 3-\mathrm{C} 4$ dihedral angle is $118^{\circ}$. Part $\mathrm{f}$; same orientation as part $\mathrm{c}$ except the $\mathrm{C} 1-\mathrm{C} 2 / \mathrm{C} 3-\mathrm{C} 4$ dihedral angle is $62^{\circ}$. 

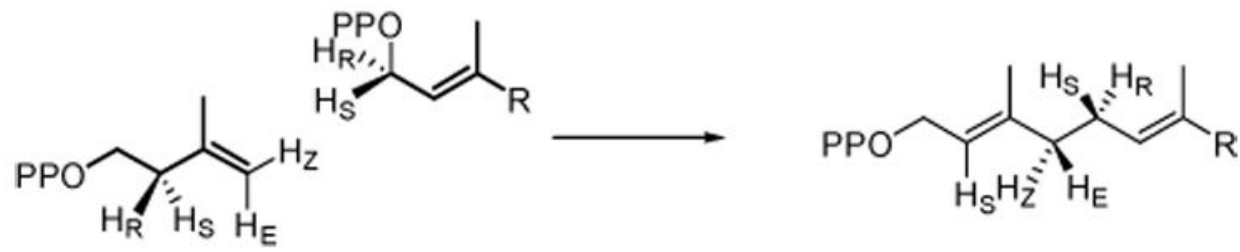

Scheme 1.

Stereochemistry of chain elongation by FPP synthase 


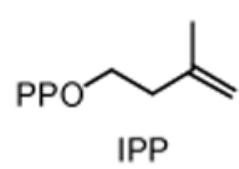<smiles>CC(C)=CCCC(C)=CCOP</smiles><smiles>COP(O)OCC=C(C)C</smiles><smiles>CC(C)=CCC/C(C)=C\COP</smiles><smiles>C=C(C)CCOP</smiles><smiles>CC(C)=CCC/C(C)=C/CC/C(C)=C/COP(=O)(O)C(F)(F)F</smiles><smiles>CC(C)=CCC/C(C)=C/COP</smiles>

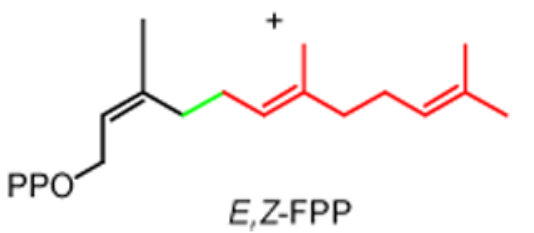

Scheme 2.

$\mathrm{C}_{5}$ to $\mathrm{C}_{10}$ and $\mathrm{C}_{10}$ to $\mathrm{C}_{15}$ Chain elongation reactions. 
<smiles>C=C(C)CCOP</smiles><smiles>[R]C(C)=CC[Po]</smiles>
PPO<smiles>[R]/C(C)=C/CC/C(C)=C/COP</smiles><smiles>C=C(C)CCOP</smiles><smiles>[R]C(C)=C=C</smiles><smiles>[3H]C</smiles><smiles>[R]C(C)=CCCC(C)CCOP</smiles>

Scheme 3.

Mechanism for chain elongation 
Table 1

Enzymes, plasmids, and E. coli host strains.

\begin{tabular}{|c|c|c|c|c|}
\hline Enzyme and Source & Plasmid & Host Strain & $\begin{array}{l}\text { Antibiotics } \\
(\mu \mathrm{g} / \mathrm{mL})\end{array}$ & Reference \\
\hline Avian FPP synthase & pMJY189 & XA-90 & Amp (100) & 2 \\
\hline Escherichia coli FPP synthase & pET15BEFDS & BL-21 & Amp (100) & 12 \\
\hline Artemisia tridentata FPP synthase & pMPM3BFDS & XA-90 & Amp (100) & 13 \\
\hline Artemisia tridentata CPP Synthase & pMPM3BCDS & XA-90 & Amp (100) & 13 \\
\hline $\begin{array}{l}\text { Artemisia tridentata GPP synthase } \\
\text { (engineered) }\end{array}$ & pMPM3BBglCV & XA-90 & Amp (100) & 14 \\
\hline $\begin{array}{c}\text { Pyrococcus furiosus FPP/GGPP } \\
\text { synthase }\end{array}$ & pPet-pf1 102 & $\begin{array}{l}\text { Rosetta(DE3) } \\
\text { pLysS }\end{array}$ & $\begin{array}{l}\operatorname{Amp}(100) \\
\text { Cam(34) }\end{array}$ & 15 \\
\hline $\begin{array}{c}\text { Methanobacter thermautotrophicus } \\
\text { FPP/GGPP synthase }\end{array}$ & pq-mth50 & RosettaBlue & $\begin{array}{l}\text { Amp (100), } \\
\text { Tet }(12.5) \\
\text { Cam }(34)\end{array}$ & 16 \\
\hline
\end{tabular}




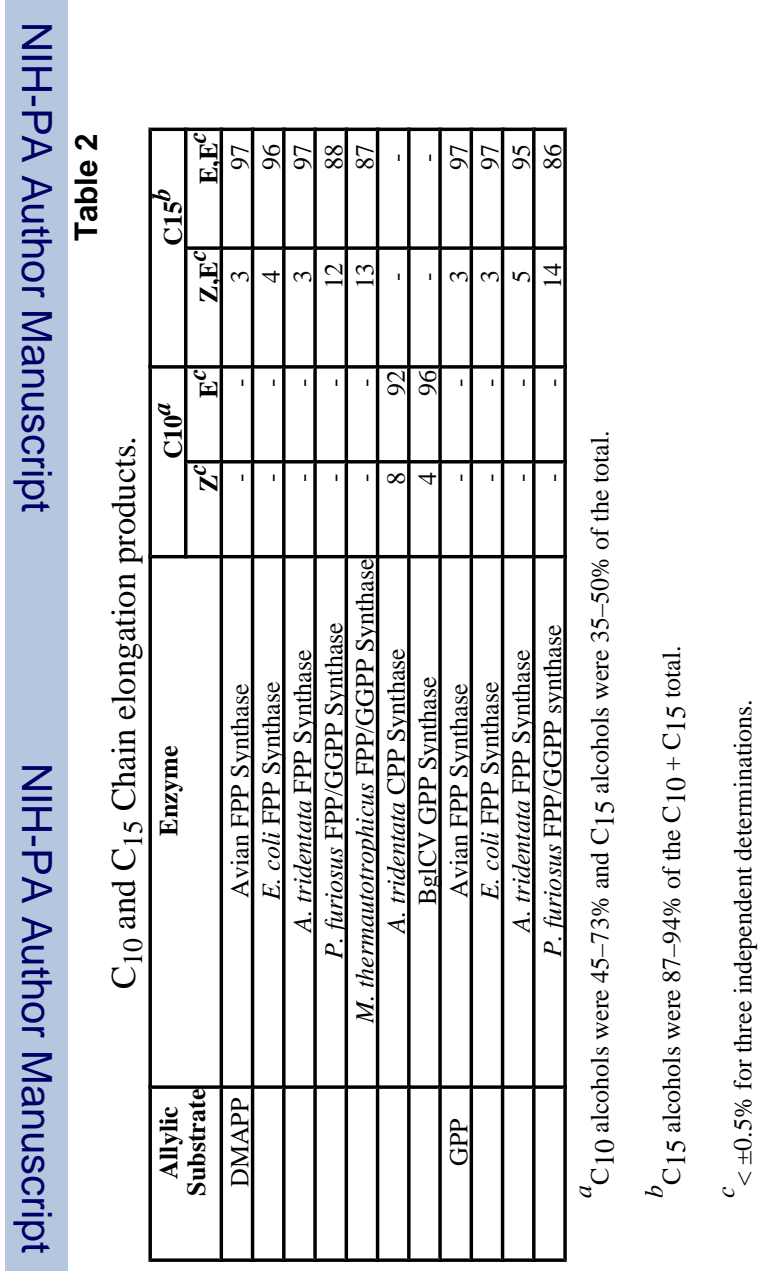




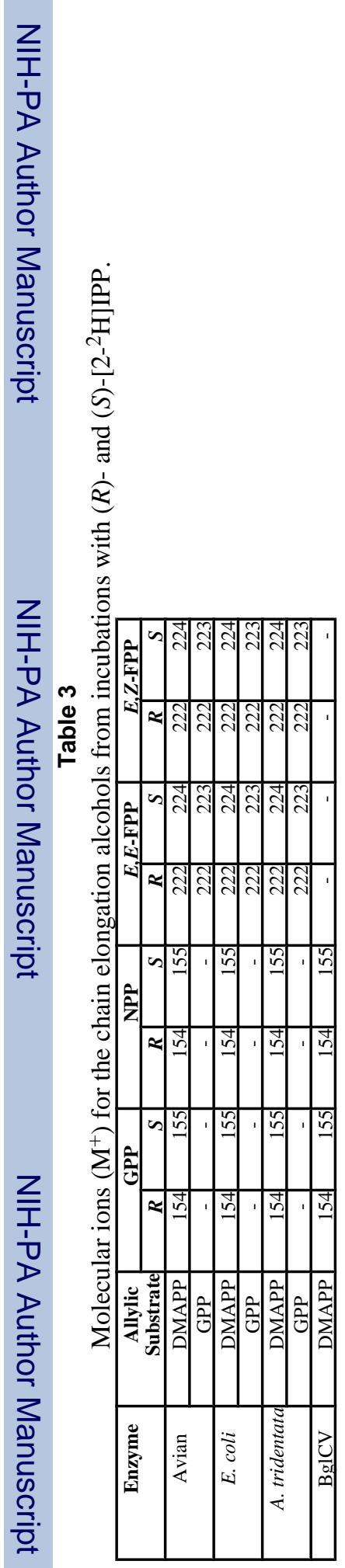

